\title{
Effects of pharmaceutically active compounds (PhACs) on fish body and scale shape in natural waters
}

\author{
Adam Staszny ${ }^{\text {Corresp., } 1}{ }^{1}$ Peter Dobosy ${ }^{2}$, Gabor Maasz ${ }^{3,4}{ }^{,}$, Zoltán Szalai ${ }^{5,6}$, Gergely Jakab ${ }^{5,6,7}$, Zsolt Pirger ${ }^{3}$, Jozsef \\ Szeberenyi ${ }^{5}$, Eva Molnar ${ }^{3}$, Lilianna Olimpia Pap ${ }^{1}$, Vera Juhász ${ }^{1}$, András Weiperth ${ }^{1}$, Béla Urbányi ${ }^{1}$, Attila Csaba \\ Kondor $^{5}$, Árpád Ferincz ${ }^{1}$ \\ 1 Department of Aquaculture, Szent István University, Gödöllő, Hungary \\ 2 Danube Research Institute, MTA-Centre for Ecological Research, Budapest, Hungary \\ 3 Balaton Limnological Institute, MTA-Centre for Ecological Research, Tihany, Hungary \\ 4 Soós Ernő Technology Research and Development Center, University of Pannonia, Nagykanizsa, Hungary \\ ${ }^{5}$ Geographical Institute, Research Centre for Astronomy and Earth Sciences, MTA Centre for Excellence, Budapest, Hungary \\ 6 Department of Environmental and Landscape Geography, Eötvös Loránd University, Budapest, Hungary \\ 7 Institute of Geography and Geoinformatics, University of Miskolc, Miskolc, Hungary \\ Corresponding Author: Adam Staszny \\ Email address: Staszny.Adam@szie.hu
}

Background. In recent years, there are growing concerns about pharmaceutically active compounds (PhACs) in natural ecosystems. These compounds have been found in natural waters and in fish tissues worldwide. Regarding their growing distribution and abundance, it is becoming clear that traditionally used risk assessment methodologies and ecotoxicological studies have limitations in several respects. In our study a new, combined approach of environmental impact assesment of PHACs has been used. Methods. In this study, the constant watercourses of the suburban region of the Hungarian capital (Budapest) were sampled, and the body shape and scale shape of three fish species (roach Rutilus rutilus, chub Squalius cephalus, gibel carp Carassius gibelio) found in these waters were analyzed, based on landmark-based geometric morphometric methods. Possible connections were made between the differences in body shape and scale shape, and abiotic environmental variables (local- and landscape-scale) and measured PhACs.

Results. Significant connections were found between shape and PhACs concentrations in several cases. Despite the relatively large number of compounds (54) detected, citalopram, propranolol, codeine and trimetazidine significantly affected only fish body and scale shape, based on their concentrations. These four PhACs were shown to be high (citalopram), medium (propranolol and codeine), and low (trimetazidine) risk levels during the environmental risk assessment, which were based on Risk Quotient (RQ) calculation. Furthermore, seven PhACs (diclofenac, Estrone (E1), tramadol, caffeine 17 $\alpha$ Ethinylestradiol (EE2), 17 $\alpha$-Estradiol (aE2), Estriol(E3)) were also categorized with a high risk level. However our mornhological studies indicated that only citalopram was found to 
affect fish phenotype amongst the PhACs posing high risk. Therefore, our results revealed that the output of (traditional) environmental/ecological risk assessment based on ecotoxicological data of different aquatic organisms not necessarily show consistency with a "real-life" situation; furthermore, the morphological investigations may also be a good sub-lethal endpoint in ecotoxicological assessments. 
1 Effects of Pharmaceutically Active Compounds

2 (PhACs) on fish body and scale shape in natural

3 waters

4

5

6

7

8

9

10

Ádám Staszny ${ }^{1}$, Péter Dobosy ${ }^{2}$, Gábor Maász ${ }^{3,4}$, Zoltán Szalai ${ }^{5,6}$, Gergely Jakab ${ }^{5,6,7}$, Zsolt Pirger $^{3}$, József Szeberényi ${ }^{5}$, Éva Molnár ${ }^{3}$, Lilianna Olimpia Pap ${ }^{1}$, Vera Juhász ${ }^{1}$, András Weiperth ${ }^{1}$, Béla Urbányi ${ }^{1}$, Attila Csaba Kondor ${ }^{5}$, Árpád Ferincz ${ }^{1}$

${ }^{1}$ Department of Aquaculture, Szent István University, Gödöllö, Hungary

${ }^{2}$ MTA-Centre for Ecological Research, Danube Research Institute, Budapest, Hungary

${ }^{3}$ MTA-Centre for Ecological Research, Balaton Limnological Institute, Tihany, Hungary

${ }^{4}$ University of Pannonia, Soós Ernő Technology Research and Development Center, Nagykanizsa, Hungary

${ }^{5}$ Geographical Institute, Research Centre for Astronomy and Earth Sciences, MTA Centre for Excellence, Budapest, Hungary

${ }^{6}$ Department of Environmental and Landscape Geography, Eötvös Loránd University, Budapest, Hungary

${ }^{7}$ Institute of Geography and Geoinformatics, University of Miskolc, Miskolc, Hungary

Corresponding Author:

Ádám Staszny ${ }^{1}$

Páter K. u. 1., Gödöllö, H-2100, Hungary

Email address: Staszny.Adam@szie.hu

\section{Abstract}

Background. In recent years, there are growing concerns about pharmaceutically active compounds (PhACs) in natural ecosystems. These compounds have been found in natural waters and in fish tissues worldwide. Regarding their growing distribution and abundance, it is becoming clear that traditionally used risk assessment methodologies and ecotoxicological studies have limitations in several respects. In our study a new, combined approach of environmental impact assesment of PHACs has been used.

Methods. In this study, the constant watercourses of the suburban region of the Hungarian capital (Budapest) were sampled, and the body shape and scale shape of three fish species (roach Rutilus rutilus, chub Squalius cephalus, gibel carp Carassius gibelio) found in these waters were analyzed, based on landmark-based geometric morphometric methods. Possible connections were made between the differences in body shape and scale shape, and abiotic environmental variables (local- and landscape-scale) and measured PhACs. 
39 Results. Significant connections were found between shape and PhACs concentrations in several

40

41

42

43

44

45

46

47

48

49

50

51

52

53

54

55

56

57

58

59

60

61

62

63

64

65

66

67

68

69

70

71

72

73

74

75

76

77

78

cases. Despite the relatively large number of compounds (54) detected, citalopram, propranolol, codeine and trimetazidine significantly affected only fish body and scale shape, based on their concentrations. These four PhACs were shown to be high (citalopram), medium (propranolol and codeine), and low (trimetazidine) risk levels during the environmental risk assessment, which were based on Risk Quotient (RQ) calculation. Furthermore, seven PhACs (diclofenac, Estrone (E1), tramadol, caffeine 17 $\alpha$-Ethinylestradiol (EE2), 17 $\alpha$-Estradiol (aE2), Estriol(E3)) were also categorized with a high risk level. However, our morphological studies indicated that only citalopram was found to affect fish phenotype amongst the PhACs posing high risk. Therefore, our results revealed that the output of (traditional) environmental/ecological risk assessment based on ecotoxicological data of different aquatic organisms not necessarily show consistency with a "real-life" situation; furthermore, the morphological investigations may also be a good sub-lethal endpoint in ecotoxicological assessments.

\section{Introduction}

The first detection of pharmaceutical active compounds (PhACs) in aquatic ecosystems and drinking water dates back to the 1980s (Richardson and Bowron, 1985; Watts et al., 1983). Since then, an emerging number of studies have reported the distribution and the potential threat posed by these compounds (Boxall et al., 2012; Datel \& Hrabankova, 2020; Dietrich, Webb \& Petry, 2002). Selective Serotonin Reuptake Inhibitors (SSRIs), $\beta$-blockers and anti-inflammatories are considered to be the most abundant drug residuals occurring in surface waters (Boxall et al., 2012). These compounds can be released into natural waters via several ways. The main sources of pollution are Wastewater Treatment Plants (WWTPs) (after the excretion of human waste) (Subedi et al., 2012), the pharmaceutical industries and the excretion of drugs from animals used in agriculture (Boxall et al., 2012). The recent technologies of WWTPs cannot eliminate these compounds fully from wastewater (Golet et al., 2001; Ternes et al., 1998; Tsui et al., 2014; Yang et al., 2020). To minimize the potential environmental risk posed by $\mathrm{PhACs}$, several regulations for ecotoxicological testing have been enacted (EMEA, 2006). In recent years, several weaknesses of these regulations have been reported in scientific articles (Ankley et al., 2007; Boxall et al., 2012) such as: (1) official tests usually use lethal endpoints, (2) little attention is paid to metabolites, (3) different regulations for human and for veterinary drugs, (4) tests for unique agents, (5) calculating the degradation of compounds and, (6) overabundant compounds (over 4.000 drug substances) to test all of them. These weaknesses and the resulting shortcomings in risk assessment procedures may cause uncertainties regarding their validity. If these points are not addressed and alternative, more adequate risk assessment techniques would not added to the regulations, then a false illusion of low risk may result in many cases. Therefore, the current shortcomings need to be examined in detail in order to better understand the problem. It is a well-known fact that several biotic and abiotic factors can influence the body shape of fish, such as food availability (Currens et al., 1989; Marcil, Swain \& Hutchings, 2006; Park et al., 2001), food type (Day, Pritchard \& Schluter, 1994), temperature (Beacham, 1990; Šumer et al.,

Peer] reviewing PDF | (2020:08:52301:2:0:NEW 30 Nov 2020) 
90

91

92

93

94

95

96

97

98

99

100

101

102

103

104

105

106

107

108

109

110

111

112

113

114

115

116

117

118

2005), and the presence or absence of predators (Brönmark \& Miner, 1992). In addition, it has also been proven that environmental parameters can affect the shape of fish scales (Ibáñez, 2015; Staszny et al., 2013; Takács et al., 2016). The effect of basic chemical parameters (e.g. ion concentrations) of the water may also affect the phenotype of fish, however their effect on the shape (body or scale) is unclarified (Çoban et al., 2013; Franklin et al., 2005; Schlenk \& Benson 2001). Due to the chronic, multigenerational exposure of fishes to PhACs, phenotypic alterations are possible, and there is evidence that progestogen contaminations can affect somatic indices (Maasz et al., 2017). Therefore, the aim of this study was (1) to find connections between the PhACs measured in small watercourses and the body and scale shape of selected fish species; and (2) to describe which type of PhACs or abiotic environmental factors are responsible for anatomical differences.

\section{Materials \& Methods}

\section{Ethics statement}

This study followed all relevant national and international guidelines concerning the care and welfare of fish (Algers et al., 2009; Johansen et al., 2006). Fish samplings were authorized by the Minister of Agriculture (Permit no.: HHgF/298-1/2016) and fish collection for laboratory examinations was authorized by the Government Office of Pest county (Permit no.: XIV-I001/2302-4/2012). During sampling, an effort was made to minimize the suffering of fish and all fish were anaesthetized with a lethal dose of clove oil after collection. No endangered species (according to the IUCN Red List of Threatened Species v. 13 [www.iucnredlist.org] and National Law Protected [www.termeszetvdelem.hu]) were caught during this study.

\section{Study area}

The study was performed in the suburban area of Budapest, which is the capital and the biggest city in Hungary and in the Carpathian Basin. Altogether, 22 points were sampled for chemical analysis during 2017-2018, and 420 specimens of three species (140 roach Rutilus rutilus, 180 chub Squalius cephalus, 100 gibel carp Carassius gibelio) were collected in 20 sampling points from 10 streams during 29 sampling occasions (Fig. 1).Body- and scale-shape data of 20 specimens/sites were included in the analyses, the number of sampling sites, where the necessary number of specimens were available has been indicated in Table 1 .

\section{Water sampling and chemical analysis}

Water samples were taken during low water-level periods. General water chemical analysis was performed in the field (Hanna $\mathrm{HI} 98194$ for dissolved $\mathrm{O}_{2}$, electric conductivity, $\mathrm{pH}$, total dissolved solids, temperature; Macherey-Nagel VisColor PF12 spectrophotometer for $\mathrm{NO}_{2}{ }^{-}$, $\left.\mathrm{NO}_{3}{ }^{-}, \mathrm{NH}_{4}{ }^{+}, \mathrm{PO}_{4}{ }^{3-}\right)$. For further laboratory analyses $\left(\mathrm{F}^{-}, \mathrm{Cl}^{-}, \mathrm{SO}_{4}{ }^{2-}, \mathrm{NO}_{2}{ }^{-}, \mathrm{NO}_{3}{ }^{-}, \mathrm{PO}_{4}{ }^{3-}, \mathrm{NH}_{4}{ }^{+}\right.$, $\mathrm{Ca}^{2+}, \mathrm{Mg}^{2+}, \mathrm{Na}^{+}, \mathrm{K}^{+}$) samples were collected in 500-ml borosilicate glass containers. Samples for total organic carbon (TOC) measurements were taken in white, borosilicate containers (50 ml sample with $500 \mu 12 \mathrm{M}$ hydrochloric acid (VWR International, Pennsylvania, USA)). For the 
120

121

122

123

124

125

126

127

128

129

130

131

132

133

134

135

136

137

138

139

140

141

142

143

144

145

146

147

148

149

150

151

152

153

154

155

156

157
119 elemental analysis, a $10-\mathrm{ml}$ water sample was filtered through a $0.45 \mu \mathrm{m}$ diameter syringe filter, acid (VWR International, Pennsylvania, USA) was added. TOC and total nitrogen (TN) concentrations were measured by using a Multi N/C 3100 TC-TN analyzer (Analytik Jena, Germany). For the determination of anions $\left(\mathrm{F}^{-}, \mathrm{Cl}^{-}, \mathrm{SO}_{4}{ }^{2-}, \mathrm{Br}^{-}, \mathrm{NO}_{3}{ }^{-}\right)$and cations $\left(\mathrm{NH}_{4}{ }^{+}, \mathrm{Ca}^{2+}\right.$, $\mathrm{Mg}^{2+}, \mathrm{Na}^{+}, \mathrm{K}^{+}$), a Dionex ICS 5000+ dual channel ion chromatograph (Thermo Fischer Scientific, USA) was used. $\mathrm{PO}_{4}{ }^{3-}, \mathrm{NO}_{2}{ }^{-}$concentrations, alkalinity as well as total hardness were measured by standard titrimetric and spectrophotometric methods (Eaton et al., 2005). The concentration of heavy metals was determined by using PlasmaQuant MS Elite inductively coupled plasma mass-spectrometer (Analytik Jena, Germany).

For the PhACs measurements, brown, a borosilicate glass container with Teflon faced caps (Thermo Fisher Scientific) was filled with a 21 water sample, into which $2 \mathrm{ml}$ of HPLC purity formic acid (VWR International, Pennsylvania, USA) was added. The samples were immediately stored in $4^{\circ} \mathrm{C}$, and transported to the laboratory in a dark cooler box (Dometic CFX40W) within 4 hours, where they were then extracted.

Details of the sample preparation, extraction and analysis process for PhACs have also been described in our earlier papers (Jakab et al., 2020; Kondor et al., 2020; Maasz et al., 2019). Briefly, for sample quantification, the water samples were acidified with formic acid and spiked with the corresponding mass-labelled internal standard (IS). Because of the relatively low concentrations, analytes were isolated by an AutoTrace 280 automatic solid-phase extraction system (Thermo Scientific) using Strata X-CW cartridges (\#8B-S035-FCH, Phenomenex). To reach the adequate sensitivity, dansyl-chloride was used in the derivatization of steroid agents. A supercritical fluid chromatography (ACQUITY UPC2 system, Waters) coupled with tandem mass spectrometry (MS/MS) (Xevo TQ-S Triple Quadrupole, Waters) was used to analyze and quantify the selected drug residues. Data were recorded by MassLynx software (V4.1 SCN950) in triplicates using TargetLynx XS software for evaluation. The compound separation was performed on an ACQUITY UPC2 BEH analytical column (\#186007607, Waters) with $3.0 \mathrm{~mm}$ $\times 100.0 \mathrm{~mm}, 1.7 \mu \mathrm{m}$ particle size.

\section{Fish sampling}

Fish were caught by electrofishing, and all sampling was undertaken based on the EU Water Framework Directive (EU WFD) (European Commission, 2009) and Hungarian Biodiversity Monitoring System (HBMS) protocols (www.termeszetvedelem.hu). Sampled watercourse sections belonged to River1 (bed width under $5 \mathrm{~m}$, water depth $<1 \mathrm{~m}$ ) and River2 (bed width over $5 \mathrm{~m}$, water depth $<2 \mathrm{~m}$ ) categories, therefore a battery-powered electrofishing device (HANS-GRASSL IG200/2) was used, with a 150-m section length wading in the water upstream. Two watercourses belonged to the River3 (bed width under $30 \mathrm{~m}$, water depth $>2 \mathrm{~m}$ ) category; therefore an aggregator-powered electrofishing device (HANS-GRASSL EL63II) was used, with a 300-m section length leading from a rubber boat going downstream. At every 
158

159

160

161

162

163

164

165

166

167

168

169

170

171

172

173

174

175

176

177

178

179

180

181

182

183

184

185

186

187

188

189

190

191

192

193

194

195

196

197

sampling point, 20 specimens comprised of common fish species (not endangered and not protected) were euthanized by using clove oil and stored at $-20^{\circ} \mathrm{C}$.

\section{Environmental characterization of sampling sites}

The most important environmental variables were recorded at two levels: local level and landscape level (Table 2). The two levels of environmental variables were analyzed separately.

\section{Morphometric analysis}

For body morphometrics, after defrosting, a high resolution digital picture was taken of the left side of all specimens using a NIKON D7200 DSLR camera, with a AF-S NIKKOR 35mm 1:1.8G objective, to avoid variability of side-effects (Takács et al., 2018). Standard length and wet weight were measured with an accuracy of $1 \mathrm{~mm}$ and $0.1 \mathrm{~g}$, respectively. Sex was determined by dissection, after the digital photo was captured (Table S1). Five well-developed scales were removed from every individuals' left side from the flank. Scales were placed between glass slides and scanned using an upper-light scanner (EPSON Perfection V850 Pro) with high resolution (2400 dpi). One scale per specimen was used for the analysis. Body and scale shape were analyzed using landmark-based geometric morphometry (Zelditch et al., 2004). Ten landmarks were placed on fish body and seven landmarks on fish scales (Fig. 2). For further multivariate analysis, we used the MorphoJ software package (Klingenberg, 2011). To derive shape variables from the raw landmark coordinates, a generalized least-squares Procrustes superimposition (GLS) was applied to scale, translate and rotate the coordinates (Rohlf, 1990). To eliminate the variances associated with allometric growth, a regression analysis was performed between the logarithm of centroid sizes and the Procrustes coordinates. The regression residuals were used for further analysis (Zelditch et al., 2004). The Procrustesdistance $(P d)$ was used in Canonical Variates Analysis (CVA) for computing group differences, and permutations tests with 1000 iterations were performed to test for significance.

\section{Ecological Risk Assessment}

Ecological risk characterization for PhACs is usually performed by calculating and categorizing a risk quotient (RQ). RQ is a ratio of MEC/PNEC, in which PNEC (predicted no effect concentration) is the estimated highest concentration of an individual $\mathrm{PhAC}$ not affecting the aquatic ecosystem, and MEC is the maximum measured environmental concentration in the studied surface water. In general, $\mathrm{RQ}<0.01$ refers to a negligible risk, $\mathrm{RQ}<0.1$ denotes a low risk, $0.1<\mathrm{RQ}<1$ indicates a medium risk, while $\mathrm{RQ}>1$ represents a high risk to the aquatic ecosystem.

PNEC derives from the ratio of available ecotoxicological data (e.g., NOEC, EC50, LC50, HC5) and an assessment factor (AF). When the PNEC value was not available in the literature, we used a selected ecotoxicological data/AF quotient keeping in mind the priorities between the raw data (e.g., applying experimental results instead of extrapolated modelled data, and chronic outcomes in place of acute test results). The magnitude of the AF varies between 1000 and 5, and it 
198

199

200

201

202

203

204

205

206

207

208

209

210

211

212

213

214

215

216

217

218

219

220

221

222

223

224

225

226

227

228

229

230

231

232

233

234

235

236

237

depends on the available ecotoxicological information. The uncertainty (i.e. AF) of the data decreases with expanding of the relevant data set. If PNEC can be calculated only based on acute test results, then $\mathrm{AF}=1000$. If $\mathrm{PNEC}$ can be derived from chronic data of a species, then $\mathrm{AF}=100$. Its value further decreases if ecotoxicological chronic test results are available at multiple different trophic levels: $\mathrm{AF}=50$ (2 levels) or $\mathrm{AF}=10$ ( 3 levels). If PNEC can be determined knowing of hazardous concentration for $5 \%$ of species investigated (HC5 based on ecotoxicological results of at least 5 species), then $\mathrm{AF}=5$. When data are available for each trophic level, the lowest concentration was selected to determine PNEC since environmental risk assessment is based on the most sensitive elements of the ecosystem (Molnar, Maász \& Pirger, 2020). PNECs with raw ecotoxicological data and AFs are presented in Table S2.

\section{Statistical analysis}

Background variables were categorized into four groups: PhAC data, general water chemistry data, local environmental variables data and landscape-scale environmental variables. All variables were numeric and $\log 10$ transformed before further analyses. An unconstrained Principal Component Analysis conducted on the shape datasets ( $\mathrm{x}$ and $\mathrm{y}$ coordinates of the regression residuals) was followed by the passive projection of the explanatory variables. The number of permutations in a Monte-Carlo simulation were set to 1000. In the first model, body shape data, while in the second model, scale shape data, were used with all the environmental variables listed in the dataset. Where forward selection revealed significant effects, variance partitioning was used to assess the relative contribution of the different variable groups (Borcard, Legendre \& Dapeau, 1992). Additional Mantel-tests were performed on shape-variables (Mahalanobis- and Procrustes-distances) and PhACs concentrations, to assess the site-specific component of differences.

\section{Results}

\section{PhAC data from sampling points}

Altogether 54 different types of PhACs were found in the water samples from the sampling points (Table 3 ). Three compounds were detected in a $\mu \mathrm{g} / 1$ concentration range in examined samples, lamotrigine (maxMEC=14 $338.3 \mathrm{ng} / \mathrm{l}$ ), caffeine (maxMEC=13 $635 \mathrm{ng} / \mathrm{l})$, and diclofenac (maxMEC=2 $201.7 \mathrm{ng} / \mathrm{l})$. The remaining $51 \mathrm{PhACs}$ were measured in a few hundred, a few tens, or a few ng/l concentration ranges each above the limit of detection. Twenty-seven PhACs were used in analysis based on their RQ-values, from which eight showed high, eight showed medium and the remaining eleven $\mathrm{PhACs}$ received a low risk classification based on the environmental risk assessment (Table 3). To perform the risk assessment using relevant ecotoxicological data, we used the AF and PNEC values of detected PhACs (see Table S2).

\section{Morphometric analysis}

Significant differences were found between the average shape of fish stocks in all three species based on both fish body- and scale shape. In the case of roach body-shape, the differences based 
238 on stream, as well as in scale shape (Fig. 3), significant differences and $P d$-values are shown in 239 Table 4 for body shape and Table 5 for scale shape.

240 Sampling points of Tápió-stream were discriminated from the others (Szent-László stream, 241 Gerje-stream) along the first axis of CVA, according roach body shape. Significant differences 242 were observed between GERTOS and every other points, based on Hotelling's t-test (Figure 3, 243 Table 4). SZEBIC has been differed significantly only from TAPTAP. Scale shape of roach 244 proved to be different in TAPUJS, than most of other sites.

245 In the case of chub body- and scale shape, there were no clear connections found with the stream 246 (Fig. 4); significant differences and $P d$-values are shown in Table 6 for body shapes and Table 7

247 for scale shapes. Figure 4 suggests negative correlation between the distance from the estuary 248 and CV2 (HOSTOR < HOSKEL < HOSKAM; BUKTOR < BUKSZE < BUKIZB) in case of 249 Hosszúréti-stream and Bükkös-stream also, however CVA-plot for scale shape not support this

250

251

252

253

254

255

256

257

258

259

260

261

262

263

264

265

266

267

268

269

270

271

272

273

274

275

276

finding. In the case of gibel carp body shape, all sampling points differed significantly. In the case of gibel carp scale shape, there was a connection with stream, but there are similarities between the sampling points from different streams as well (Fig. 5); significant differences and $P d$-values are shown in Table 8 for body shape and Table 9 for scale shape. Interesting pattern of sites could be observed in case of gibel carp body shape, since within-stream difference (GERTOR -GERCEG seems to be higher than between-stream (GERTOR - SZEBIC; GERTOR - HOSKEL) difference. Regarding gibel carp scale, GERTOR site have not been differed such harshly from others, like in case of body shape. BENBIA proved to be the most different site along CV1.

\section{Significant background variables}

Numerous significant background variables were found, which affect fish body shape and scale shape. Local- and landscape-scale environmental variables, water chemistry data and also $\mathrm{PhACs}$ were found to be significant. In case of roach scale shape, the significant variables were As (9\%) and $\mathrm{SO}_{4}{ }^{2-}(3 \%)$, and for body shape, TRIM (6\%), and CITA (4\%) were found to be significant ( $1 \%$ joint effect). In the case of chub scale shape, water chemistry data (significant variables: $\mathrm{Mg}, \mathrm{As}, \mathrm{Ca}$ ) was responsible for $5 \%$ of the variance, local environmental variables (significant variables: emergent macrophytes, water depth) were responsible for $2 \%$ of the variance, while PhACs (significant variable: CODE) were responsible for $1 \%$ of the variance. The local environmental variables and CODE had $1 \%$ joint effect. In the case of chub body shape, only two variables were significant, $\mathrm{Cd}$ as water chemistry data and detritus as a local environmental variable, for $4 \%$ and $3 \%$ respectively, with $8 \%$ joint effect. In the case of gibel carp scale shape, the water chemistry variable $\mathrm{Pb}(2 \%)$ and the landscape scale environmental variable wetland (6\%) were significant, with $1 \%$ joint effect. For gibel carp body shape, three different type of variables were significant, the PPCB PROP, the water chemistry variable $\mathrm{Zn}$, and the landscapescale environmental variable catchment size, for $6 \%, 11 \%$ and $2 \%$ respectively, with $4 \%$ joint effect for $\mathrm{Zn}$ and catchment size (Table 10).

Peer) reviewing PDF | (2020:08:52301:2:0:NEW 30 Nov 2020) 
277 Mantel tests did not show significant correlation among the site-specific shape variables and the 278 significant background variables, in most of the cases (Table S3). In case of chub scale, Ca 279 shows significant correlation with Procrustes-distances, although in case of Mahalanobis280 distances the correlation was not significant. In case of roach scale, both As and $\mathrm{SO}_{4}{ }^{2-}$ showed 281 significant correlation with Mahalanobis-distances, although in case of Procrustes-distances the 282 correlation was not significant.

283

284 Discussion

285 Our results indicated that PhACs can influence fish body shape and scale shape in natural 286 environments and habitats. There are several studies that showed shape differences between fish 287 stocks in natural waters (Ibáñez \& Jawad, 2018; Takács et al., 2016). These studies usually 288 explain the variations by different genetic background (Lõhmus et al., 2010; Staszny et al., 289 2013), phenotypic plasticity (Vasconcellos et al., 2008), or some basic environmental 290 differences, such as food availability (Currens et al., 1989; Marcil, Swain \& Hutchings, 2006; 291 Park et al., 2001), temperature (Lõhmus et al., 2010; Šumer et al., 2005), flow-regime (Haas, 292 Blum \& Heins, 2010). These effects, and their combination have also affected the phenotype of 293 fish included this study. Moreover, the observed impact of PhACs on shape is considered to 294 relatively small, however it should be taken into consideration during the the studies, carried out 295 in natural waters. In addition, the results of this study suggest that the mixtures of PhACs that 296 occur in natural waters have different effects on different species and phenotypes such as body 297 and scale.

298

299

300

\section{Potential effects of environmental variables on shape}

In the case of chub and gibel carp, significant environmental variables were found. The effects of

301 local (section) level variables on chub scale shape could be explained by the life-history characteristics of the species. Different environmental characteristics of the given habitats may cause changes at the population level (Haas, Blum \& Heins, 2010). Coverage of emergent macrophytes, water depth and the quantity of detritus were previously found to be connected to the life history parameters of chub (Bolland, Cowx \& Lucas, 2008; Ünver \& Erk-Akan, 2011), therefore these variables might affect the scale and body shape of the fish. In the case of gibel carp, significant environmental variables included landscape-scale variables, wetland (scale shape) and catchment size (body shape). There are several known examples regarding the shapemodification effects of environmental differences in fish. Species of the genus Carassius are characterized by a high level of phenotypic plasticity. In the case of crucian carp (Carassius carassius), the presence or absence of predators and the feeding behavior (zooplankton versus

312 benthic chironomids) have a complex effect on body shape (Andersson, Johansson \& Söderlund, 313 2006).

314

\section{Potential effects of general water chemistry on scale shape}


316 Water chemistry had a significant impact on roach and chub scale shape. The effects of arsenic

317 (As) on muscle development in fish have already been reported (D'Amico, 2012), and this

318 compound can accumulated in scales (Allen et al. 2004) as well, which might affect scale shape

319 itself. Fliedner et al. (2014) studied the water chemistry, especially the heavy metal

320 concentrations in rivers Rhine, Elbe, Danube, Saar, Mulde, Saale and in Lake Belau in Germany.

321 Throughout the study $\mathrm{As}, \mathrm{Pb}, \mathrm{Cu}$ and $\mathrm{Hg}$ concentrations were measured from tissue samples of

322 zebra mussel (Dreissena polymorpha) and bream (Abramis brama). Arsenic found to be the only

323 compound, where increase in concentration was detectable while analyzing in bream muscle

324

325

326

327

328

329

330

331

332

333

334

335

336

337

338

339

340

341

342

343

344

345

346

347

348

349

350

351

352

353

354

355 tissue samples from 1990s to 2014 (Fliedner et al., 2014). $\mathrm{Mg}^{2+}$ and $\mathrm{Ca}^{2+}$ significantly impacted the scale shape of chub. $\mathrm{Ca}^{2+}$ is an essential building component of fish scales (Sankar et al., 2008) while the $\mathrm{Mg}^{2+}$ content of water affects calcium uptake in fish (Dabrowska, MeyerBurgdorff \& Gunther, 1991, Van der Velden et al., 1991). Cadmium is a $\mathrm{Ca}^{2+}$ uptake inhibiting agent which was also shown to affect chub body shape. The presence of $\mathrm{Cd}$ has a negative effect on $\mathrm{Ca}^{2+}$ uptake through the gills (Franklin et al., 2005). Lead concentrations are also connected to gibel carp scale shape formation. This heavy metal cannot be excreted physiologically (via the gills or kidneys), and $\mathrm{Pb}$ impairs fish scale development to a greater extent than in other organs (Coban et al., 2013). Zinc also has a significant impact on gibel carp body shape, and is associated with higher (11\%) variance. Zinc uptake is related to $\mathrm{Ca}^{2+}$ concentrations where high $\mathrm{Ca}^{2+}$ concentrations may decrease $\mathrm{Zn}$ uptake; excess $\mathrm{Zn}$ then accumulates in fish skin, muscle and bones (Hogstrand \& Wood, 1996), and therefore might have an effect on body shape.

\section{Potential effect of PhACs on shape}

TRIM is a cytoprotective, anti-ischemic agent with a strong antioxidant effect (Sedky et al., 2017). In zebrafish (Danio rerio) TRIM can decrease the ototoxic effects of neomycin on haircell loss in the neuromasts (Chang et al., 2013). Phenotypic alterations have not been discussed previously, however, a significant effect was detected on roach body shape in this study.

Citalopram, as a SSRI, have also been shown to significantly affect roach body shape. A strong anxiolytic effect has been reported in fish previously (Olsén et al., 2014, Porseryd et al., 2017), and alterations in behavioral patterns might also affect the phenotype as well, because the use of different habitats might alter the phenotype of different species (Faulks et al., 2015). Codeine, an opiate derivative, is used to treat rheumatic pain (Ytterberg, Mahowald \& Woods, 1998), and significantly modulates chub-scale shape. There is evidence of the presence of codeine in fish tissues (Epple et al., 1993; Valdés et al., 2016), however, phenotypic alterations have not been detected. It might be in relation with the inhibition of the expression of receptors for vascular endothelial growth factor, which can affect the early life-stage development of fish (Karaman et al., 2017). PROP, a non-selective $\beta$-blocker, affected gibel carp body shape. It is used to treat heart diseases, and has proved to be the cause of decreased testosterone and estradiol levels in zebrafish, and has showed anxiolytic effects, and decreased growth (Mitchell \& Moon, 2016). As we discussed in the case of roach and CITA, the anxiolytic effects of drugs might also alter phenotype. Based on RQ-values, CITA was ranked to be high risk, while CODE and PROP were 
356

357

358

359

360

361

362

363

364

365

366

367

368

369

370

371

372

373

374

375

376

377

378

379

380

381

382

383

384

385

386

387

388

389

390

391

392

393

394

395

medium risk, and TRIM was low risk. These results also suggest that the widely used "traditional" risk assessment may have weaknesses when compared to a "real-life" measured effects.

\section{Conclusions}

In summary, our results suggest that PhACs in natural waters can affect the phenotypic characteristics of fish species. Although a relatively large number of PhACs (54 compounds) were found in the water samples, only 4 compounds were found to have significant effects on phenotype. This study did not aim to find clear cause and effect relationships between the given compounds, or to reveal the mode-of-actions; however, the individual-scale effect of PhACs was identified. The results of this study showed that differences in phenotype can be detected, therefore the morphometric analysis was suitable for an alternative, sub-lethal endpoint of environment-level toxicological investigation. However, in order to get a more accurate picture of the actual phenotypic effect of PhACs in the environment, a more detailed study with a larger sample size is needed. Since the effects of PhACs on scale shape have been observed, scale sampling may be a suitable, effective and ethically acceptable tool to extend studies on different river systems.

\section{Acknowledgements}

The authors thank Andrew J. Hamer (University of Melbourne, ELKH Centre for Ecological Research, Balaton Limnological Institute) for the English proofread, Petra Dragán (Szent István University) and Igor Dukay (Renatur Bt.) for define WWTWs location.

\section{References}

Algers B., Blokhuis HJ, Bøtner A, Broom DM, Costa P, Domingo M, Greiner M, Hartung J, Koenen F, Müller-Graf C, Morton DB, Osterhaus A, Pfeiffer DU, Raj M, Roberts R, Sanaa M, Salman M, Sharp JM, Vannier P, Wierup M. 2009. General approach to fish welfare and to the concept of sentience in fish. Scientific Opinion of the Panel on Animal Health and Welfare. The EFSA Journal 954:1-27.

Allen T, Awasthi A, Rana SVS. 2004. Fish chromatophores as biomarkers of arsenic exposure. Environmental Biology of Fishes 71:7-11 DOI: 10.1023/B:EBFI.0000043145.58953.86.

Andersson J, Johansson F, Söderlund T. 2006. Interactions between predator- and diet-induced phenotypic changes in body shape of crucian carp. Proceedings of the Royal Society B: Biological Sciences 273:431-437 DOI: 10.1098/rspb.2005.3343.

Ankley GT, Brooks BW, Huggett DB, Sumpter JP. 2007. Repeating History: Pharmaceuticals in the Environment. Environmental Science \& Technology 41(24):8211-8217 DOI: 10.1021/es072658j.

Beacham TD. 1990. A Genetic Analysis of Meristic and Morphometric Variation in Chum Salmon (Oncorhynchus keta) at Three Different Temperatures. Canadian Journal of Zoology 68:225-229 DOI: 10.1139/z90-033. 
396

397

398

399

400

401

402

403

404

405

406

407

408

409

410

411

412

413

414

415

416

417

418

419

420

421

422

423

424

425

426

427

428

429

430

431

432

433

434

Bolland JD, Cowx IG, Lucas MC. 2008. Movements and habitat use of wild and stockedjuvenile chub, Leuciscus cephalus (L.), in a smalllowland river. Fisheries Management and Ecology 15:401-407 DOI: 10.1111/j.1365-2400.2008.00631.x.

Borcard D, Legendre P, Dapeau P. 2012. Partialling out the spatial component of ecological variation. Ecology 73:1045-1055 DOI: 10.2307/1940179.

Boxall AB, Rudd MA, Brooks BW, Caldwell DJ, Choi K, Hickmann S, Innes E, Ostapyk K, Staveley JP, Verslycke T, Ankley GT, Beazley KF, Belanger SE, Berninger JP, Carriquiriborde P, Coors A, Deleo PC, Dyer SD, Ericson JF, Gagné F, Giesy JP, Gouin T, Hallstrom L, Karlsson MV, Larsson DGJ, Lazorchak JM, Mastrocco F, McLaughlin A, McMaster ME, Meyerhoff RD, Moore R, Parrott JL, Snape JR, Murray-Smith R, Servos MR, Sibley PK, Straub JO, Szabo ND, Topp E, Tetreault GR, Trudeau VL, Van der Kraak G. 2012. Pharmaceuticals and personal care products in the environment: what are the big questions? Environmental Health Perspectives 120(9):1221-1229 DOI: 10.1289/ehp.1104477. Brönmark C, Miner JG. 1992. Predator-induced Phenotypical Change in Body Morphology in Crucian Carp. Science 258:1348-1350 DOI: 10.1126/science.258.5086.1348.

Chang J, Im GJ, Chae SW, Lee SH, Kwon S-Y, Jung HH, Chung A-Y, Park H-C, Choi J. 2013. Protective Role of Trimetazidine Against Neomycin-induced Hair Cell Damage in Zebrafish. Clinical and Experimental Otorhinolaryngology 6(4):219-225 DOI: 10.3342/ceo.2013.6.4.219.

Çoban MZ, Eroğlu M, Canpolat Ö, Çalta M, Şen D. 2013. Effect of Chromium on Scale Morphology in Scaly Carp (Cyprinus carpio L.). Journal of Animal and Plant Sciences 23(5):1455-1459.

Currens KP, Sharpe CS, Hjort R, Schreck CB, Li HW. 1989. Effects of Different Feeding Regimes on the Morphometrics of Chinook Salmon (Oncorhynchus tshawytscha) and Rainbow Trout (O. mykiss). Copeia 3:689-695 DOI: 10.2307/1445496.

D’Amico A. 2012. Arsenic Affects Muscle Development and Structure in Fundulus heteroclitus. All Theses 1491 https://tigerprints.clemson.edu/all theses/1491

Dabrowska H, Meyer-Burgdorff KH, Gunther K-D. 1991. Magnesium status in freshwater fish, common carp (Cyprinus carpio, L.) and the dietary protein-magnesium interaction. Fish Physiology and Biochemistry 9(2):165-172 DOI: 10.1007/BF02265132.

Datel JV, Hrabankova A. 2020. Pharmaceuticals Load in the Svihov Water Reservoir (Czech Republic) and Impacts on Quality of Treated Drinking Water. Water 12:1387 DOI: 10.3390/w12051387.

Day T, Pritchard J, Schluter D. 1994. A Comparison of Two Sticklebacks. Evolution 48:17231734 DOI: 10.1111/j.1558-5646.1994.tb02208.x.

Dietrich DR, Webb SF, Petry T. 2002. Hot spot pollutants: pharmaceuticals in the environment. Toxicology Letters 131:1-3 DOI: 10.1016/s0378-4274(02)00062-0.

Eaton AD, Clesceri LS, Rice EW, Greenberg AE. 2005. Standard Methods for the Examination of Water and Wastewater, 21st ed. Washington, D.C.: APHA-AWWA-WEF 
435

436

437

438

439

440

441

442

443

444

445

446

447

448

449

450

451

452

453

454

455

456

457

458

459

460

461

462

463

464

465

466

467

468

469

470

471

472

473

474

EMEA, 2006. Guideline on the Environmental Risk Assessment for Medicinal Products for Human Use, CHMP/SWP/4447/00. Available at: http://www.ema.europa.eu/documents/scientific-guideline/guideline-environmental-riskassessment-medicinal-products-human-use-first-version en.pdf (accessed 25 August 2020).

Epple A, Navarrol I, Horak P, Spector S. 1993. Endogenous Morphine and Codeine: Release by the Chromaffin Cells of the Eel. Life Sciences 52:117-121 DOI: 10.1016/00243205(93)90175-3.

European Commission, 2009. Common Implementation Strategy for the Water Framework Directive (2000/60/EC); Guidance document n.o 7. Monitoring under the Water Framework Directive. Available at: http://circabc.europa.eu/sd/a/63f7715f-0f45-4955-b7cb58ca305e42a8/Guidance\%20No\%207\%20-\%20Monitoring\%20(WG\%202.7).pdf (accessed 25 August 2020).

Faulks L, Svanbäck R, Eklöv P, Östman Ö. 2015. Genetic and morphological divergence along thelittoral-pelagic axis in two common and sympatricfishes: perch, Perca fluviatilis (Percidae) and roach, Rutilus rutilus (Cyprinidae). Biological Journal of the Linnean Society London 114:929-940 DOI: 10.1111/bij.12452.

Fliedner A, Rüdel H, Knopf B, Weinfurter K, Paulus M, Ricking M, Koschorreck J. 2014. Spatial and temporal trends of metals and arsenic in German freshwater compartments.

Environmental Science and Pollution Research 21:5521-5536 DOI: 10.1007/s11356-0132487-y.

Franklin NM, Glover CN, Nicol JA, Wood CM. 2005. Calcium/cadmium Interactions at Uptake Surfaces in Rainbow Trout: Waterborne Versus Dietary Routes of Exposure. Environmental Toxicology and Chemistry 24(11):2954-2964 DOI: 10.1897/05-007r.1.

Golet EM, Alder AC, Hartmann A, Ternes TA, Giger W. 2001. Trace Determination of Fluoroquinolone Antibacterial Agents in Urban Wastewater by Solid-Phase Extraction and Liquid Chromatography with Fluorescence Detection. Analytical Chemistry 73(15):36323638 DOI: $10.1021 /$ ac0015265.

Haas TC, Blum MJ, Heins DC. 2010. Morphological responses of a stream fish to water impoundment. Biological Letters 6:803-806 DOI: 10.1098/rsbl.2010.0401.

Hogstrand C, Wood CM. 1996. The physiology and toxicology of zinc in fish. In Taylor EW, ed. Toxicology of Aquatic Pollution-Physiological, Molecular, and Cellular Approaches. Society for Experimental Biology Seminar Series 57. Cambridge: Cambridge University Press, 61-84.

Ibáñez AL. 2015. Fish traceability: Guessing the origin of fish from a seafood market using fish scale shape. Fisheries Research 170:82-88 DOI: 10.1016/j.fishres.2015.05.016.

Ibáñez AL, Jawad LA. 2018. Morphometric variation of fish scales among some species of rattail fish from New Zealand waters. Journal of the Marine Biological Association of the United Kingdom 98(8):1991-1998 DOI: 10.1017/S0025315418000024.

Jakab G, Szalai Z, Michalkó G, Ringer M, Filep T, Szabó L, Maász G, Pirger Zs, Ferincz Á, Staszny Á, Dobosy P, Kondor ACs. 2020. Thermal baths as sources of pharmaceutical and 
475

476

477

478

479

480

481

482

483

484

485

486

487

488

489

490

491

492

493

494

495

496

497

498

499

500

501

502

503

504

505

506

507

508

509

510

511

512

513

514

illicit drug contamination. Environmental Science and Pollution Research 27:399-410 DOI: 10.1007/s11356-019-06633-6.

Johansen R, Needham JR, Colquhon DJ, Poppe TT, Smith AJ. 2006. Guidelines for health and welfare monitoring of fish used in research. Laboratory Animals 40:323-340. DOI: $10.1258 / 002367706778476451$

Karaman H, Tufek A, Karaman E, Tokgoz O. 2017. Opioids inhibit angiogenesis in a chorioallantoic membrane model. Pain Physician 20(2S):E11-E21.

Klingenberg CP. 2011. MorphoJ: an integrated software package for geometric morphometrics. Molecular Ecology Resources 11:353-357 DOI: 10.1111/j.1755-0998.2010.02924.x.

Kondor ACs, Jakab G, Vancsik A, Filep T, Szeberényi J, Szabó L, Maász G, Ferincz Á, Dobosy P, Szalai Z. 2020. Occurrence of pharmaceuticals in the Danube and drinking water wells: Efficiency of riverbank filtration. Environmental Pollution 265(Pt A):114893 DOI: 10.1016/j.envpol.2020.114893.

Lõhmus M, Sundström LF, Björkland M, Devlin RH. 2010. Genotype-temperature interaction in the regulation of development, growth, and morphometrics in wild-type, and growth-hormone transgenic coho salmon. PLoS ONE 5(4):e9980 DOI: 10.1371/journal.pone.0009980.

Maasz G, Zrinyi Z, Takacs P, Lovas S, Fodor I, Kiss T, Pirger Zs. 2017. Complex molecular changes induced by chronic progestogens exposure in roach, Rutilus rutilus. Ecotoxicology and Environmental Safety 139:9-17 DOI: 10.1016/j.ecoenv.2017.01.020.

Maasz G, Mayer M, Zrinyi Z, Molnar E, Kuzma M, Fodor I, Pirger Z, Takács P. 2019. Spatiotemporal variations of pharmacologically active compounds in surface waters of a summer holiday destination. Science of the Total Environment 677:545-555 DOI: 10.1016/j.scitotenv.2019.04.286.

Marcil J, Swain DP, Hutchings JA. 2006. Genetic and Environmental Components of Phenotypic Variation in Body Shape Among Populations of Atlantic cod (Gadus morhua). Biological Journal of the Linnean Society London 88:351-365 DOI: 10.1111/j.1095-8312.2006.00656.x.

Mitchell KM, Moon TW. 2016. Behavioral and Biochemical Adjustments of the Zebrafish Danio Rerio Exposed to the $\beta$-blocker Propranolol. Comparative Biochemistry and Physiology Part B: Biochemistry and Molecular Biology 199:105-114 DOI: 10.1016/j.cbpb.2015.10.009.

Molnar E, Maász G, Pirger Zs. 2020. Environmental risk assessment of pharmaceuticals at a seasonal holiday destination in the largest freshwater shallow lake in Central Europe.

Environmental Science and Pollution Research 1-28 DOI: 10.1007/s11356-020-09747-4.

Olsén KH, Ask K, Olsén H, Porsch-Hällström I, Hallgren S. 2014. Reprint of "Effects of the SSRI citalopram on behaviours connected tostress and reproduction in Endler guppy, Poecilia wingei”. Aquatic Toxicology 151:97-104 DOI: 10.1016/j.aquatox.2014.02.011.

Park I-S, Im JH, Ryu DK, Nam YK, Kim DS. 2001. Effect of Starvation on Morphometric Changes in Rhynchocypris oxycephalus (Sauvage and Dabry). Journal of Applied Ichthyology 17:277-281 DOI: 10.1046/j.1439-0426.2001.00298.x.

Porseryd T, Kellner M, Caspillo NR, Volkova K, Elabbas L, Ullah S, Olsén H, Dinnétz P, Hällström IP. 2017. Combinatory Effects of Low Concentrations of $17 \alpha$-etinylestradiol and 
515

516

517

518

519

520

521

522

523

524

525

526

527

528

529

530

531

532

533

534

535

536

537

538

539

540

541

542

543

544

545

546

547

548

549

550

551

552

\section{Citalopram on Non-Reproductive Behavior in Adult Zebrafish (Danio Rerio). Aquatic} Toxicology 193:9-17 DOI: 10.1016/j.aquatox.2017.10.001.

Richardson ML, Bowron JM. 1985. The fate of pharmaceutical chemicals in the aquatic environment: A review. Journal of Pharmacy and Pharmacology 37:1-12 DOI: 10.1111/j.2042-7158.1985.tb04922.x.

Rohlf FJ. 1990. Morphometrics. Annual Review of Ecology, Evolution, and Systematics 21:299316 DOI: 10.1146/annurev.es.21.110190.001503.

Sankar S, Sekar S, Mohan R, Rani S, Sundaraseelan J, Sastry TP. 2008. Preparation and partial characterization of collagen sheet from fish (Lates calcarifer) scales. International Journal of Biological Macromolecules 42(1):6-9 DOI: 10.1016/j.ijbiomac.2007.08.003.

Schlenk D, Benson WH. 2001. New Perspectives: Toxicology and the Environment Volume 1. Target Organ Toxicity in Marine and Freshwater Teleosts. London and New York: Taylor \& Francis. p 426.

Sedky AA, El Serafy OMH, Hassan OA, Abdel-Kawy HS, Hasanin AH, Raafat MH. 2017. Trimetazidine potentiates the antiepileptic activity and ameliorates the metabolic changes associated with pentylenetetrazole kindling in rats treated with valproic acid. Canadian Journal of Physiology and Pharmacology 95(6):686-696 DOI: 10.1139/cjpp-2016-0263. Staszny Á, Havas E, Kovács R, Urbányi B, Paulovits G, Bencsik D, Ferincz Á, Müller T, Specziár A, Bakos K, Csenki Zs. 2013. Impact of environmental and genetic factors on the scale shape of zebrafish, Danio rerio (Hamilton 1822): A geometric morphometric study. Acta Biologica Hungarica 64(4):462-475 DOI: 10.1556/ABiol.64.2013.4.6.

Subedi B, Du B, Chambliss CK, Koschorreck J, Rüdel H, Quack M, Brooks BW, Usenko S. 2012. Occurrence of pharmaceuticals and personal care products in German fish tissue: a national study. Environmental Science \& Technology 46(16):9047-9054 DOI: 10.1021/es301359t.

Šumer S, Kováč V, Povž M, Slatner M. 2005. External morphology of a Slovenian population of pumpkinseed Lepomis gibbosus (L.) from a habitat with extreme thermal conditions. Journal of Applied Ichthyology 21:306-311 DOI: 10.1111/j.1439-0426.2005.00691.x.

Takács P, Vitál Z, Ferincz Á, Staszny Á. 2016. Repeatability, Reproducibility, Separative Power and Subjectivity of Different Fish Morphometric Analysis Methods. Plos ONE 11(6):e0157890 DOI: 10.1371/journal.pone.0157890.

Takács P, Ferincz Á, Staszny Á, Vitál Z. 2018. Effect of bodyside-specific data processing on the results of fish morphometric studies. Fundamental and Applied Limnology 192(2):137144 DOI: $10.1127 / \mathrm{fal} / 2018 / 1159$.

Ternes T, Hirsch R, Mueller J, Haberer K. 1998. Methods for the determination of neutral drugs as well as betablockers and alpha2-sympathomimetics in aqueous matrices using GC/MS and LC/MS/MS. Fresenius' Journal of Analytical Chemistry 362:329-340 DOI: $10.1007 / \mathrm{s} 002160051083$. 
553 Tsui MMP, Leung HW, Lam PKS, Murphy MB. 2014. Seasonal occurrence, removal

554

555

556

557

558

559

560

561

562

563

564

565

566

567

568

569

570

571

572

573

574

575

576

577

578

579

580

581

582

583

584

efficiencies and preliminary risk assessment of multiple classes of organic UV filters in wastewater treatment plants. Water Research 53:58-67 DOI: 10.1016/j.watres.2014.01.014.

Ünver B, Erk'akan F. 2011. Diet composition of chub, Squalius cephalus (Teleostei: Cyprinidae), in Lake Tödürge, Sivas, Turkey. Journal of Applied Ichthyology 27(6):13501355 DOI: 10.1111/j.1439-0426.2011.01766.x.

Valdés ME, Huerta B, Wunderlin DA, Bistoni MA, Barceló D, Rodriguez-Mozaz S. 2016.

Bioaccumulation and bioconcentration of carbamazepine and other pharmaceuticals in fish under field and controlled laboratory experiments. Evidences of carbamazepine metabolization by fish. Science of the Total Environment 557-558:58-67 DOI: 10.1016/j.scitotenv.2016.03.045.

Van der Velden JA, Spanings FAT, Flik G, Zegers C, Kolar ZI, Wendelaar Bonga SE. 1991. Growth rate and tissue magnesium concentration in adult freshwater tilapia, Oreochvomis rnossarnbicus (Peters), fed diets differing in magnesium content. Journal of Fish Biology 39:83-91 DOI: 10.1111/j.1095-8649.1991.tb04343.x.

Vasconcellos AV, Vianna P, Paiva PC, Schama R, Solé-Cava A. 2008. Genetic and morphometric differences between yellowtail snapper (Ocyurus chrysurus, Lutjanidae) populations of the tropical West Atlantic. Genetics and Molecular Biology 31(1, Suppl.):308316 DOI: $10.1590 / \mathrm{S} 1415-47572008000200026$.

Watts CD, Crathorne M, Fielding M, Steel CP. 1983. Identification of non-volatile organics in water using field desorption mass spectrometry and high performance liquid chromatography. In: Angeletti G, ed. Analysis of Organic Micropollutants in Water. Dotrecht: Reidel Publ. Corp., 120-131.

Yang H, Lu G, Yan Z, Liu J, Dong H, Bao X, Zhang X, Sun Y. 2020. Residues, bioaccumulation, and trophic transfer of pharmaceuticals and personal care products in highly urbanized rivers affected by water diversion. Journal of Hazardous Materials 391:122245 DOI: $10.1016 /$ j.jhazmat.2020.122245.

Ytterberg SR, Mahowald ML, Woods SR. 1998. Codeine and oxycodone use in patients with chronic rheumatic disease pain. Arthritis \& Rheumatology 41(9):1603-1612 DOI: 10.1002/1529-0131(199809)41:9<1603::aid-art10>3.0.co;2-u.

Zelditch ML, Swiderski DL, Sheets HD, Fink WL. 2004. Geometric morphometrics for biologists: A primer. New York: Elsevier Academic Press. 
Figure 1

Sampling points with sufficient individuals. Red vertical arrows shows WWTPs introductions.

C - chub, R - roach, GC - gibel carp; 1 - MORVER, 2 - GOMVAC, 3 - BUKIZB, 4 - BUKSZE, 5 BUKTOR, 6 - SZEBIC, 7 - BENBIA, 8 - HOSKAM, 9 - HOSKEL, 10 - HOSTOR, 11 - DTCDUN, 12 VALBAR, 13 - TAPTAP, 14 - TAPSZE, 15 - TAPGYO, 16 - TAPUJS, 17 - GERCEG, 18 - GERTOR, 19 - GERKOR, 20 - GERTOS.

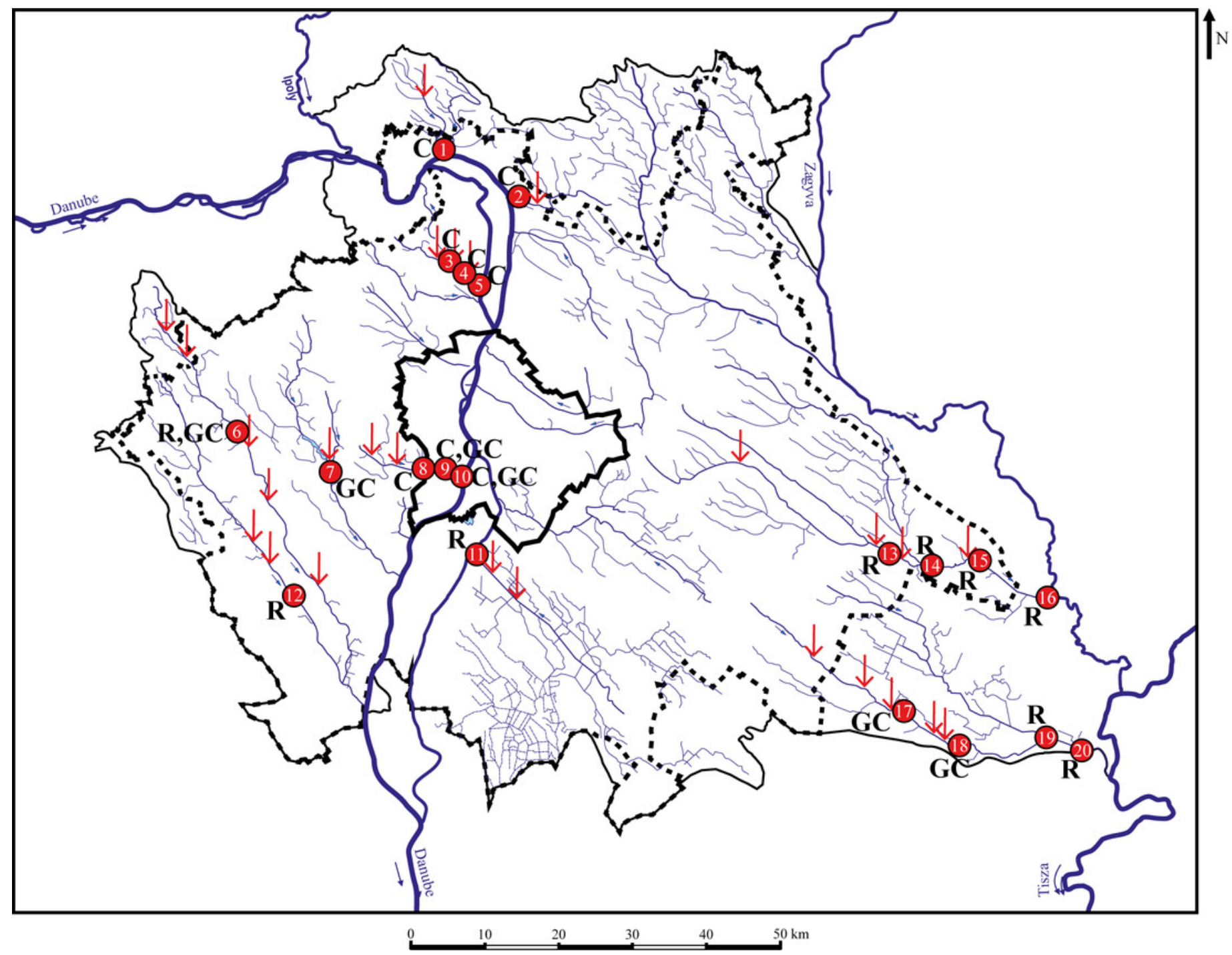


Figure 2

Morphometric landmarks on (A) a schematic gibel carp (Carassius gibelio) and a gibel carp scale, (B) a schematic roach (Rutilus rutilus) and a roach scale, (C) a schematic chub (Squalius cephalus) and a chub scale.
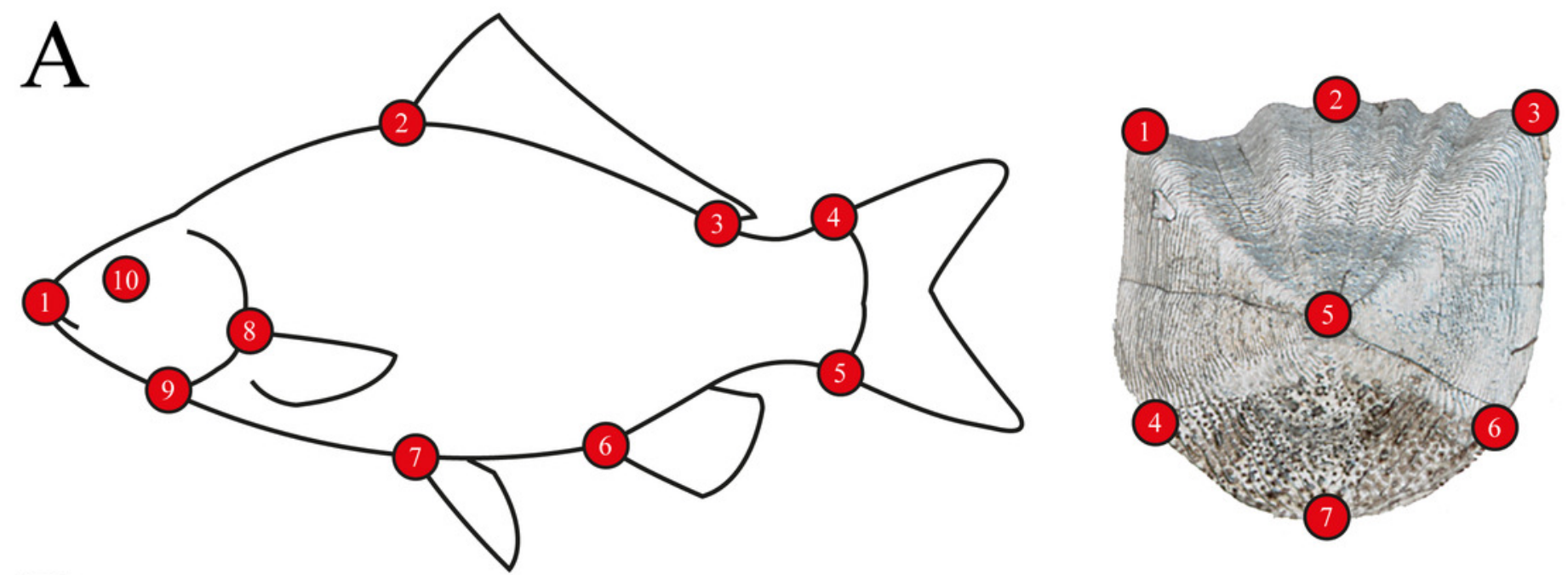

B
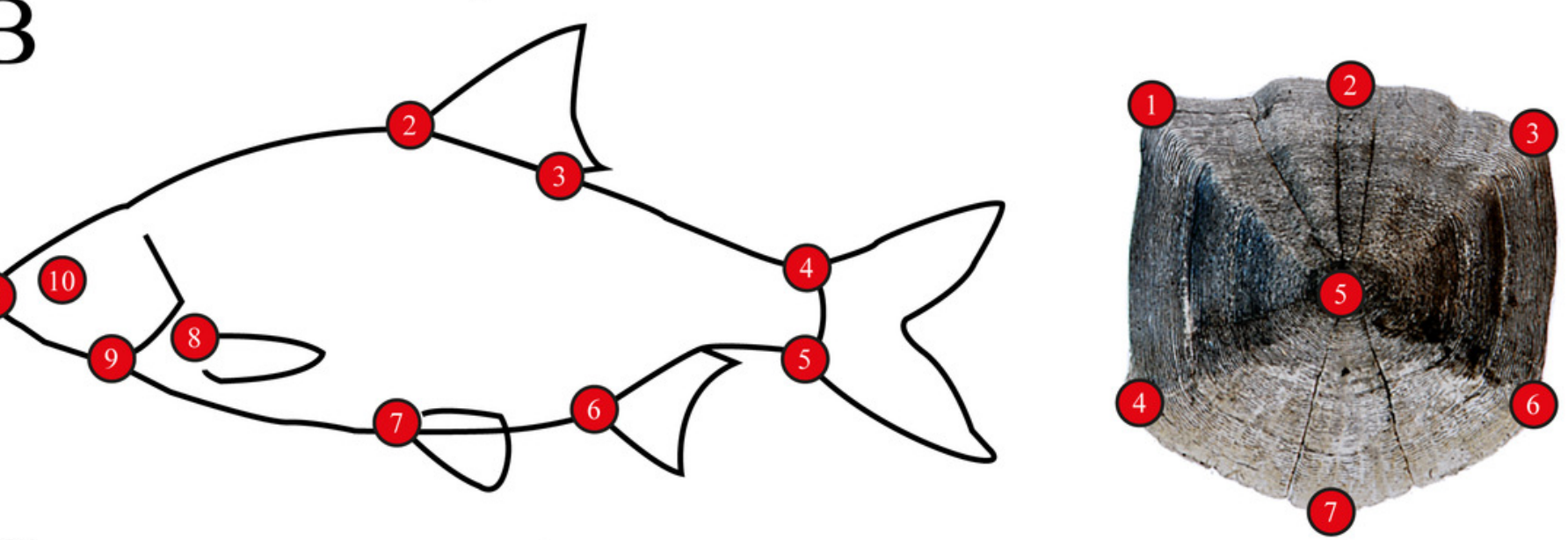

$\mathrm{C}$
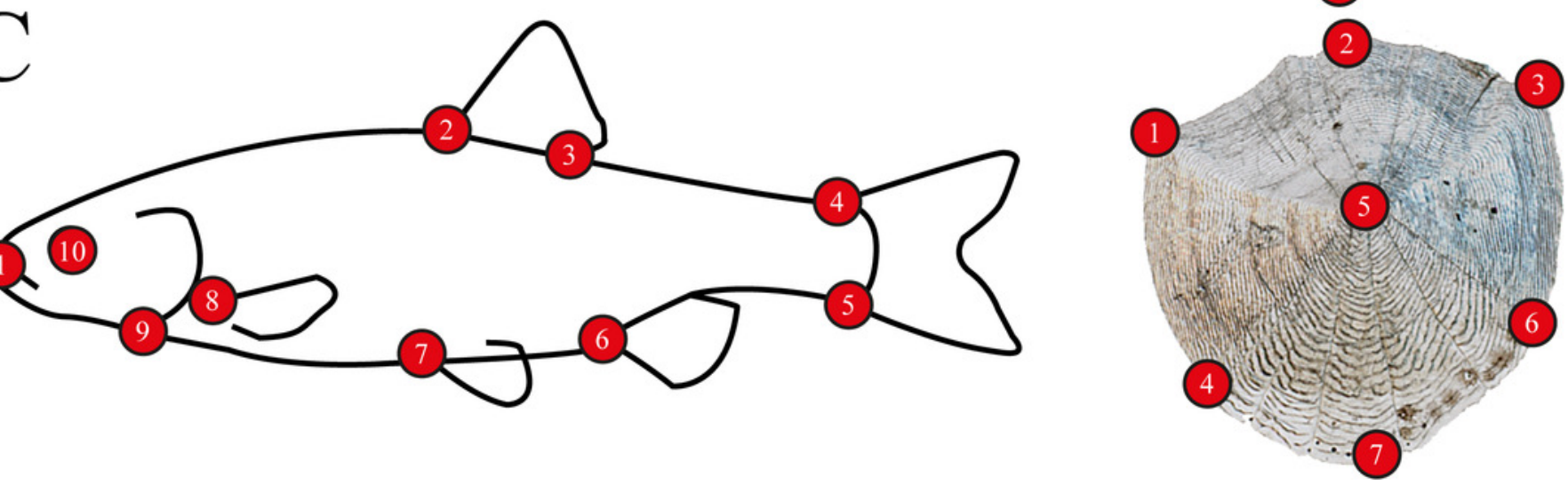
Figure 3

Canonical Variates Analysis (CVA) results of roach (Rutilus rutilus) body shape (A) and scale shape (B).

Small-case letters indicate significant differences based on Procrustes-distances, upper-case letters indicate the sampling points (first three letters indicates the stream). Symbols show the group centroids, crosshairs show the standard deviations. 

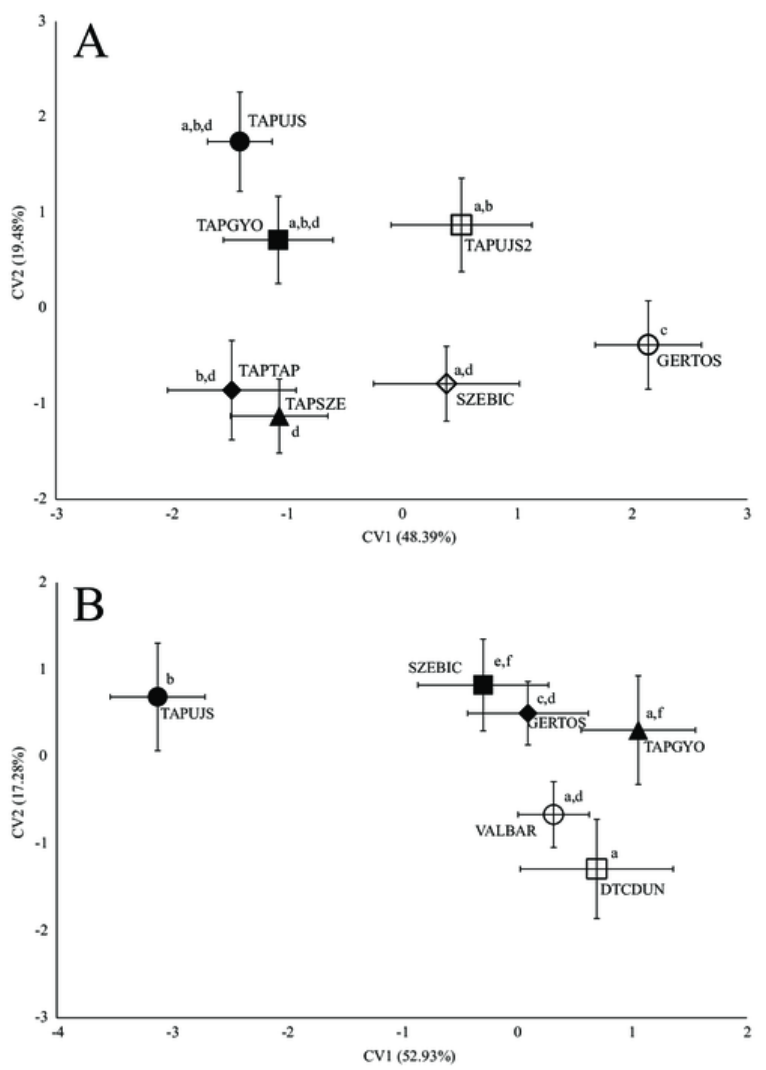
Figure 4

Canonical Variates Analysis (CVA) results of chub (Squalius cephalus) body shape (A) and scale shape (B).

Small-case letters indicate significant differences based on Procrustes-distances, upper-case letters indicate the sampling points (first three letters indicates the stream). Symbols show the group centroids, crosshairs show the standard deviations. 


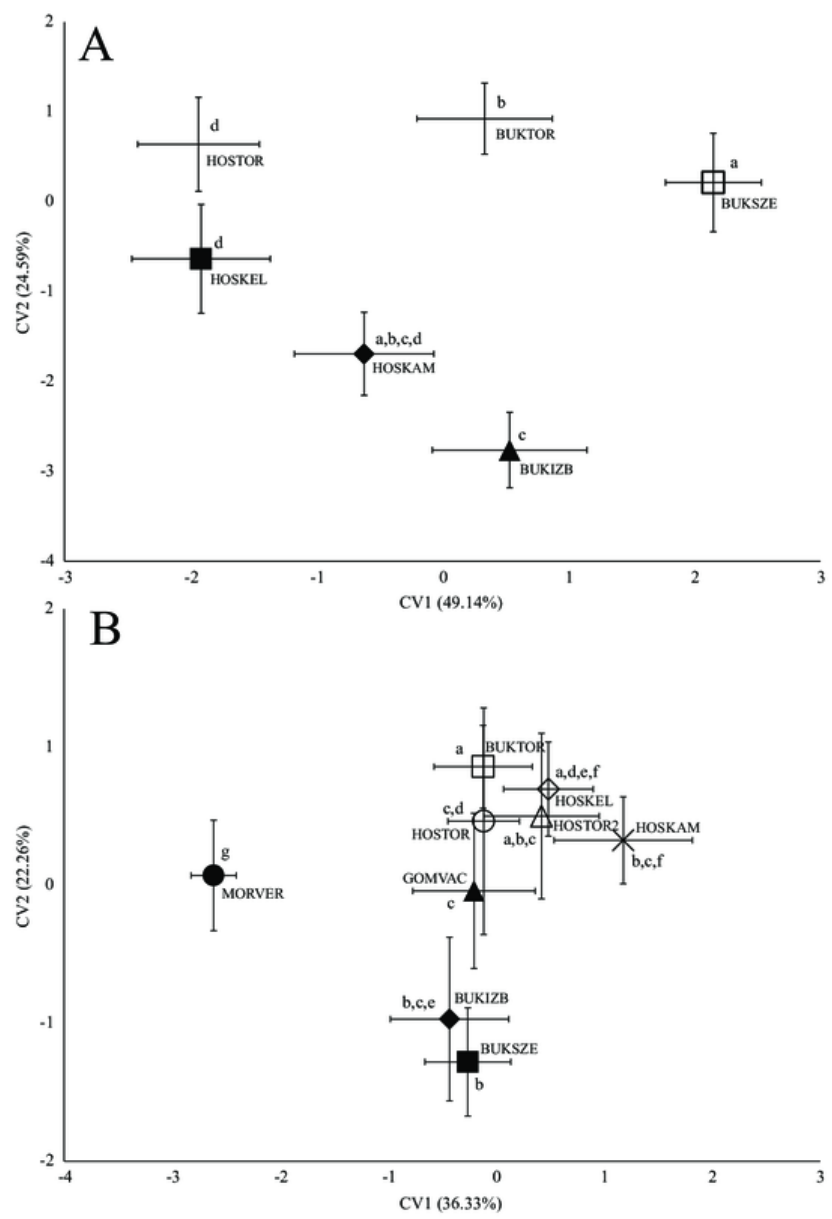




\section{Figure 5}

Canonical Variates Analysis (CVA) results of gibel carp (Carassius gibelio) body shape (A) and scale shape (B).

Small-case letters indicate significant differences based on Procrustes-distances, upper-case letters indicate the sampling points (first three letters indicates the stream). Symbols show the group centroids, crosshairs show the standard deviations. 

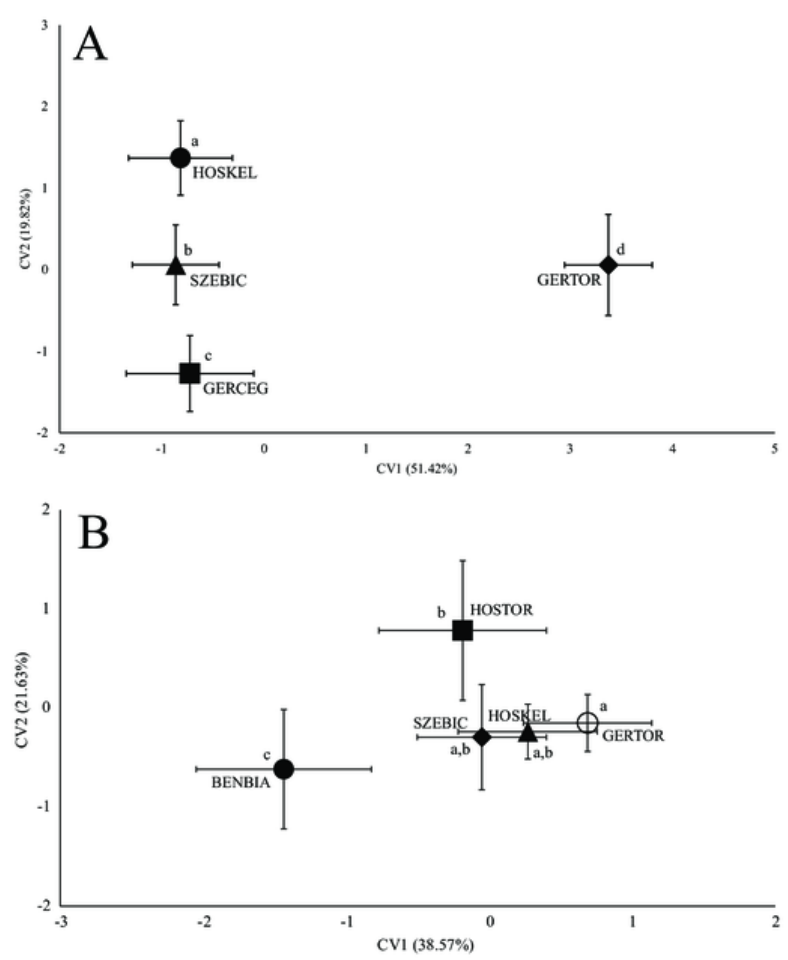


\section{Table $\mathbf{1}$ (on next page)}

Number of sampled species and sampling points. 
1 Table 1. Number of sampled species and sampling points.

Fish species

roach (Rutilus rutilus)

roach (Rutilus rutilus)

chub (Squalius cephalus)

chub (Squalius cephalus)

gibel carp (Carassius gibelio)

gibel carp (Carassius gibelio)
No. of sampling points

6

7

9

6

5

4
No. of individuals / sampling points

20

20

20

20

20

20
Suitable data for analysis

scale

body

scale

body

scale

body 
Table 2 (on next page)

Local- and landscape-scale environmental variables used to characterize sampling points. 
1 Table 2. Local- and landscape-scale environmental variables used to characterize sampling 2 points.

\begin{tabular}{|c|c|c|c|}
\hline & Name & Abbreviation & Measure \\
\hline \multirow[t]{15}{*}{$\begin{array}{l}\text { Local } \\
\text { environmental } \\
\text { characteristics }\end{array}$} & $\begin{array}{l}\text { Woody stemmed coastal } \\
\text { vegetation within } 1 \mathrm{~m} \text { from } \\
\text { riverbed }\end{array}$ & wood $1 \mathrm{~m}$ & $\begin{array}{l}\text { Shoreline coverage } \\
(\%)\end{array}$ \\
\hline & $\begin{array}{l}\text { Woody stemmed coastal } \\
\text { vegetation within } 10 \mathrm{~m} \text { from } \\
\text { riverbed }\end{array}$ & wood 10m & $\begin{array}{l}\text { Shoreline coverage } \\
(\%)\end{array}$ \\
\hline & $\begin{array}{l}\text { Soft stemmed coastal vegetation } \\
\text { within } 1 \mathrm{~m} \text { from riverbed }\end{array}$ & soft $1 \mathrm{~m}$ & $\begin{array}{l}\text { Shoreline coverage } \\
(\%)\end{array}$ \\
\hline & $\begin{array}{l}\text { Soft stemmed coastal vegetation } \\
\text { within } 10 \mathrm{~m} \text { from riverbed }\end{array}$ & soft $10 \mathrm{~m}$ & $\begin{array}{l}\text { Shoreline coverage } \\
(\%)\end{array}$ \\
\hline & Riverbed width & width & $\mathrm{m}$ \\
\hline & Water depth & depth & $\mathrm{cm}$ \\
\hline & Flow rate & flow & $\mathrm{m} / \mathrm{s}$ \\
\hline & Sediment - detritus & detritus & $\begin{array}{l}\text { Bottom coverage } \\
(\%)\end{array}$ \\
\hline & Sediment - mud & mud & $\begin{array}{l}\text { Bottom coverage } \\
(\%)\end{array}$ \\
\hline & Sediment - sand & sand & $\begin{array}{l}\text { Bottom coverage } \\
(\%)\end{array}$ \\
\hline & Sediment- gravel & gravel & $\begin{array}{l}\text { Bottom coverage } \\
(\%)\end{array}$ \\
\hline & Sediment - stone & stone & $\begin{array}{l}\text { Bottom coverage } \\
(\%)\end{array}$ \\
\hline & Bottom- rock & rock & $\begin{array}{l}\text { Bottom coverage } \\
(\%)\end{array}$ \\
\hline & Bottom - concrete & concrete & $\begin{array}{l}\text { Bottom coverage } \\
(\%)\end{array}$ \\
\hline & Macrophyte coverage & macrophyte & Coverage $(\%)$ \\
\hline \multirow{6}{*}{$\begin{array}{l}\text { Landscape- } \\
\text { scale } \\
\text { environmental } \\
\text { characteristics }\end{array}$} & $\begin{array}{l}\text { Catchment size over the sampling } \\
\text { point }\end{array}$ & catch.size & $\mathrm{km}^{2}$ \\
\hline & Inhabited area in the catchment & inhab.area & $\mathrm{km}^{2}$ \\
\hline & $\begin{array}{l}\text { Size of artificial surface in the } \\
\text { catchment }\end{array}$ & art.surface & $\mathrm{km}^{2}$ \\
\hline & $\begin{array}{l}\text { Agricultural surface in the } \\
\text { catchment }\end{array}$ & agri.surface & $\mathrm{km}^{2}$ \\
\hline & Forest vegetation in the catchment & forest & $\mathrm{km}^{2}$ \\
\hline & Non-forest vegetation in the & non-forest & $\mathrm{km}^{2}$ \\
\hline
\end{tabular}


catchment

Wetland area in the catchment wetland $\mathrm{km}^{2}$

Lakes above the sampling point lakes

Distance from estuary distance $\mathrm{km}$

Distance from the nearest known wastewater.dis $\mathrm{km}$

wastewater discharge

Altitude of sampling point altitude m

Average altitude of the catchment avg.altitude $\mathrm{m}$ 


\section{Table 3 (on next page)}

Measured Pharmaceutically Active Compounds (PhACs) from the water samples of sampling points.

Compounds in bold were used in analysis based on their Risk Quotient (RQ), compounds in italics had a significant effect on fish shape, n.d. - no data. 
1 Table 3. Measured Pharmaceutically Active Compounds (PhACs) from the water samples 2 of sampling points.

\begin{tabular}{|c|c|c|c|c|c|c|c|}
\hline \multirow{2}{*}{ PhACs } & \multirow{2}{*}{ Abbr. } & LOQ & \multirow{2}{*}{$\begin{array}{c}\text { No. of } \\
\text { sampling } \\
\text { points found }\end{array}$} & \multirow[t]{2}{*}{ PNEC } & $\operatorname{maxMEC}$ & \multirow{2}{*}{ RQ } & \multirow{2}{*}{ Risk level } \\
\hline & & $\mathrm{ng} / \mathrm{L}$ & & & $\mathrm{g} / \mathrm{L}$ & & \\
\hline diclofenac & DICL & 0.5 & 20 & 2201.700 & $1.06 \mathrm{E}+01$ & 207.708 & \multirow{8}{*}{ high risk } \\
\hline estrone & E1 & 0.05 & 20 & 38.161 & $1.00 \mathrm{E}+00$ & 38.161 & \\
\hline tramadol & TRAM & 0.1 & 20 & 454.580 & $3.20 \mathrm{E}+01$ & 14.206 & \\
\hline caffeine & CAFF & 10 & 20 & 13635 & $2.32 \mathrm{E}+03$ & 5.877 & \\
\hline 17a-ethinylestradiol & EE2 & 0.05 & 7 & 2.241 & $4.40 \mathrm{E}-01$ & 5.093 & \\
\hline 17 $\alpha$-estradiol & $\mathbf{a E 2}$ & 0.05 & 1 & 8.491 & $2.00 \mathrm{E}+00$ & 4.245 & \\
\hline estriol & $\mathbf{E 3}$ & 0.05 & 2 & 1.578 & 4.65E-01 & 3.394 & \\
\hline citalopram & CITA & 0.1 & 20 & 20.942 & $1.00 E+01$ & 2.094 & \\
\hline theophylline & THEO & 10 & 20 & 874.173 & $1.00 \mathrm{E}+03$ & 0.874 & \multirow{8}{*}{ medium risk } \\
\hline temazepam & TEMA & 0.1 & 15 & 4.504 & $7.08 \mathrm{E}+00$ & 0.636 & \\
\hline 17ß-estradiol & bE2 & 0.05 & 16 & 0.972 & $2.00 \mathrm{E}+00$ & 0.486 & \\
\hline metoclopramide & MCLO & 0.2 & 15 & 23.626 & $5.60 \mathrm{E}+01$ & 0.422 & \\
\hline propranolol & PROP & 0.1 & 20 & 14.870 & $4.11 E+01$ & 0.362 & \\
\hline codeine & CODE & 5 & 1 & 20.030 & $6.00 E+01$ & 0.334 & \\
\hline clozapine & CLOZ & 0.1 & 20 & 53.478 & $2.85 E+02$ & 0.188 & \\
\hline trazodone & TRAZ & 0.05 & 3 & 1.032 & $9.00 \mathrm{E}+00$ & 0.115 & \\
\hline losartan & LOSA & 0.1 & 20 & 165.930 & $1.90 \mathrm{E}+03$ & 0.087 & \multirow{11}{*}{ low risk } \\
\hline carbamazepine & CARB & 0.1 & 20 & 821.385 & $1.00 \mathrm{E}+04$ & 0.082 & \\
\hline propafenone & PROF & 0.5 & 20 & 80.350 & $1.02 E+03$ & 0.079 & \\
\hline ketamin & KETA & 0.5 & 15 & 47.717 & $8.61 \mathrm{E}+02$ & 0.055 & \\
\hline lidocaine & LIDO & 0.1 & 20 & 133.910 & $2.61 E+03$ & 0.051 & \\
\hline bisoprolol & BISO & 0.5 & 16 & 154.720 & $3.15 E+03$ & 0.049 & \\
\hline alprazolam & ALP & 0.1 & 20 & 20.561 & $5.08 E+02$ & 0.040 & \\
\hline trimetazidine & TRIM & 20 & 5 & 209.463 & $6.55 E+03$ & 0.032 & \\
\hline tiapride & TIPA & 0.1 & 20 & 177.606 & $8.72 E+03$ & 0.020 & \\
\hline naproxen & NAPR & 0.1 & 1 & 287.130 & $1.51 \mathrm{E}+04$ & 0.019 & \\
\hline midazolam & MIDA & 0.1 & 5 & 4.371 & $2.89 \mathrm{E}+02$ & 0.015 & \\
\hline paracetamol & PARA & 20 & 1 & 550.820 & $5.72 \mathrm{E}+04$ & 0.010 & \multirow{4}{*}{$\begin{array}{l}\text { negligiable } \\
\text { risk }\end{array}$} \\
\hline cocaine & COCA & 0.05 & 11 & 21.840 & $2.28 \mathrm{E}+03$ & 0.010 & \\
\hline zolpidem & ZOLP & 0.01 & 18 & 4.384 & $5.19 \mathrm{E}+02$ & 0.008 & \\
\hline bupropion & BUPR & 0.5 & 8 & 7.432 & $9.50 \mathrm{E}+02$ & 0.008 & \\
\hline
\end{tabular}




\begin{tabular}{lcccccc} 
betaxolol & BET & 0.5 & 7 & 6.350 & $1.24 \mathrm{E}+03$ & 0.005 \\
oxazepam & OXAZ & 0.1 & 11 & 5.581 & $1.92 \mathrm{E}+03$ & 0.003 \\
metoprolol & MPRO & 0.1 & 20 & 150.161 & $6.15 \mathrm{E}+04$ & 0.002 \\
nordiazepam & NORD & 0.1 & 9 & 2.750 & $1.19 \mathrm{E}+03$ & 0.002 \\
mirtazapine & MIRT & 0.1 & 20 & 66.310 & $3.20 \mathrm{E}+04$ & 0.002 \\
pethidine & PETH & 0.1 & 13 & 1.218 & $6.89 \mathrm{E}+02$ & 0.002 \\
risperidone & RISP & 0.1 & 1 & 1.230 & $1.12 \mathrm{E}+03$ & 0.001 \\
zopiclone & ZOPI & 0.1 & 1 & 2.750 & $4.75 \mathrm{E}+03$ & 0.001 \\
fentanyl & FENT & 0.1 & 2 & 0.307 & $5.39 \mathrm{E}+02$ & 0.001 \\
olanzapine & OLAN & 5 & 13 & 54.071 & $1.41 \mathrm{E}+05$ & $3,83 \times 10^{-4}$ \\
verapamil & VERA & 0.05 & 7 & 10.920 & $3.60 \mathrm{E}+04$ & $3,03 \times 10^{-4}$ \\
perindopril & PERI & 0.1 & 20 & 285.461 & $9.90 \mathrm{E}+05$ & $2,88 \times 10^{-4}$ \\
diazepam & DIAZ & 0.1 & 2 & 0.605 & $2.60 \mathrm{E}+03$ & $2,33 \times 10^{-4}$ \\
carvedilol & CARV & 0.1 & 1 & 0.330 & $1.55 \mathrm{E}+03$ & $2,12 \times 10^{-4}$ \\
ethylmorphine & EMOR & 0.5 & 12 & 15.869 & $1.33 \mathrm{E}+05$ & $1,19 \times 10^{-4}$ \\
lamotrigine & LAMO & 5 & 20 & 14338.300 & $1.50 \mathrm{E}+08$ & $9,56 \times 10^{-5}$ \\
quetiapine & QUET & 0.1 & 1 & 0.830 & $1.00 \mathrm{E}+04$ & $8,30 \times 10^{-5}$ \\
warfarin & WARF & 0.1 & 3 & 0.880 & $1.20 \mathrm{E}+04$ & $7,33 \times 10^{-5}$ \\
methadone & METH & 0.02 & 3 & 1.202 & $3.81 \mathrm{E}+04$ & $3,15 \times 10^{-5}$ \\
benzoyl-ecgonine & BEC & 0.1 & 13 & 2.223 & $6.81 \mathrm{E}+06$ & $3,26 \times 10^{-7}$ \\
\hline cinolazepam & CINO & 0.1 & 20 & 394.197 & n.d. & n.d. \\
drospirenone & DROS & 1 & 2 & 2.999 & n.d. & n.d. \\
lacosamide & LACO & 0.5 & 18 & 82.549 & n.d. & n.d.
\end{tabular}

3 Compounds in bold were used in analysis based on their Risk Quotient (RQ), compounds in 4 italics had a significant effect on fish shape, n.d. - no data. 


\section{Table 4 (on next page)}

Procrustes-distances $(P d)$ and p-values of Canonical Variates Analysis on roach (Rutilus rutilus) body shape.

Significant differences are in bold. 
1 Table 4. Procrustes-distances $(P d)$ and p-values of Canonical Variates Analysis on roach

2 (Rutilus rutilus) body shape.

\begin{tabular}{lllllllll} 
& \multicolumn{1}{c}{$\mathrm{p}$-values } \\
& GERTOS & SZEBIC & TAPTAP & \multicolumn{1}{l}{ TAPUJS } & TAPGYO & TAPSZE & TAPUJS2 \\
GERTOS & & $\mathbf{0 . 0 1 1}$ & $\mathbf{0 . 0 0 0 3}$ & $\mathbf{0 . 0 4 5 6}$ & $\mathbf{0 . 0 0 7 4}$ & $\mathbf{0 . 0 3 8 7}$ & $\mathbf{0 . 0 3 3 7}$ \\
SZEBIC & $\mathbf{0 . 0 3 5 3}$ & & $\mathbf{0 . 0 2 1 6}$ & 0.1186 & 0.0803 & 0.1031 & 0.7363 \\
TAPTAP & $\mathbf{0 . 0 3 5 8}$ & $\mathbf{0 . 0 3 0 2}$ & & 0.1444 & 0.1225 & 0.7136 & $\mathbf{0 . 0 2 6 9}$ \\
¿ & & & 0.5425 & 0.4209 & 0.6972 \\
TAPUJS & $\mathbf{0 . 0 3 7 2}$ & 0.0305 & 0.0288 & & 0.5425 & 0.6884 & 0.5946 \\
TAPGYO & $\mathbf{0 . 0 3 0 2}$ & 0.0218 & 0.0197 & 0.0181 & & & 0.3427 \\
TAPSZE & $\mathbf{0 . 0 3 0 8}$ & 0.0235 & 0.0138 & 0.0233 & 0.0131 & & \\
TAPUJS2 & $\mathbf{0 . 0 2 9 8}$ & 0.015 & $\mathbf{0 . 0 2 8 4}$ & 0.02 & 0.0149 & 0.0213 &
\end{tabular}

3 Significant differences are in bold.

4 


\section{Table 5 (on next page)}

Procrustes-distances $(P d)$ and p-values of Canonical Variates Analysis on roach (Rutilus rutilus) scale shape.

Significant differences are in bold. 
1 Table 5. Procrustes-distances $(P d)$ and p-values of Canonical Variates Analysis on roach

2 (Rutilus rutilus) scale shape.

\begin{tabular}{lllllll} 
& & \multicolumn{5}{c}{-values } \\
& & & & & TAPGY & VALBA \\
& DTCDUN & GERTOS & SZEBIC & TAPUJS & O & R \\
DTCDUN & & $\mathbf{0 . 0 2 1 3}$ & $\mathbf{0 . 0 1 6 6}$ & $\mathbf{0 . 0 0 1 2}$ & 0.4392 & 0.3091 \\
GERTOS & $\mathbf{0 . 0 4 0 8}$ & & $\mathbf{0 . 0 4 9 5}$ & $<.0001$ & $\mathbf{0 . 0 3 0 9}$ & 0.0639 \\
¿ & & & $\mathbf{0 . 0 3 7 8}$ & 0.1134 & $\mathbf{0 . 0 4 4}$ \\
SZEBIC & $\mathbf{0 . 0 5 7 6}$ & $\mathbf{0 . 0 3 4 4}$ & & & $<.0001$ & $\mathbf{0 . 0 0 0 6}$ \\
TAPUJS & $\mathbf{0 . 0 9 8 5}$ & $\mathbf{0 . 0 7 5 3}$ & $\mathbf{0 . 0 5 1}$ & & & 0.4209 \\
TAPGYO & 0.0289 & $\mathbf{0 . 0 3 3 2}$ & 0.036 & $\mathbf{0 . 0 8 1 9}$ & & \\
VALBAR & 0.0323 & 0.0312 & $\mathbf{0 . 0 4 3 2}$ & $\mathbf{0 . 0 8 6 2}$ & 0.0243 &
\end{tabular}

3 Significant differences are in bold.

4 


\section{Table 6 (on next page)}

Procrustes-distances $(P d)$ and $p$-values of Canonical Variates Analysis on chub (Squalius cephalus) body shape.

Significant differences are in bold. 
1 Table 6. Procrustes-distances $(P d)$ and p-values of Canonical Variates Analysis on chub

2 (Squalius cephalus) body shape.

\begin{tabular}{llllllll} 
& \multicolumn{8}{c}{ p-values } \\
& & BUKIZB & BUKSZE & BUKTOR & HOSKAM & HOSKEL & HOSTOR \\
BUKIZB & & $\mathbf{0 . 0 0 5 1}$ & $\mathbf{0 . 0 0 5 2}$ & 0.2253 & $\mathbf{0 . 0 4 4 1}$ & $\mathbf{0 . 0 2 2 6}$ \\
BUKSZE & $\mathbf{0 . 0 2 9 2}$ & & $\mathbf{0 . 0 0 4 6}$ & 0.085 & $\mathbf{0 . 0 0 0 1}$ & $<.0001$ \\
$\approx$ & BUKTOR & $\mathbf{0 . 0 2 8 5}$ & $\mathbf{0 . 0 1 8}$ & & 0.1404 & $\mathbf{0 . 0 0 1 4}$ & $\mathbf{0 . 0 0 0 6}$ \\
$\approx$ & HOSKAM & 0.0254 & 0.0235 & 0.021 & & 0.2441 & 0.149 \\
HOSKEL & $\mathbf{0 . 0 2 5 5}$ & $\mathbf{0 . 0 3 6 1}$ & $\mathbf{0 . 0 2 5 8}$ & 0.023 & & 0.374 \\
HOSTOR & $\mathbf{0 . 0 2 5 3}$ & $\mathbf{0 . 0 3 4 7}$ & $\mathbf{0 . 0 2 3 7}$ & 0.0238 & 0.0135 &
\end{tabular}

3 Significant differences are in bold.

4 


\section{Table 7 (on next page)}

Procrustes-distances $(P d)$ and p-values of Canonical Variates Analysis on chub (Squalius cephalus) scale shape.

Significant differences are in bold. 
1 Table 7. Procrustes-distances $(P d)$ and p-values of Canonical Variates Analysis on chub (Squalius cephalus) scale shape.

\begin{tabular}{llllllllllll}
\multicolumn{10}{c}{ p-values } \\
BUKIZB & BUKIZB & BUKSZE & BUKTOR & GOMVAC & HOSTOR & HOSKAM & HOSKEL & HOSTOR2 & MORVER \\
BUKSZE & 0.018 & & 0.8553 & $\mathbf{0 . 0 0 9 2}$ & 0.1659 & $\mathbf{0 . 0 4 3 1}$ & $\mathbf{0 . 0 4 1 7}$ & 0.0673 & 0.6136 & $\mathbf{0 . 0 0 0 7}$ \\
BUKTOR & $\mathbf{0 . 0 4 2 6}$ & $\mathbf{0 . 0 5 0 5}$ & & $\mathbf{0 . 0 0 0 1}$ & $\mathbf{0 . 0 1 2 8}$ & $\mathbf{0 . 0 0 0 2}$ & 0.0552 & $\mathbf{0 . 0 0 1 8}$ & 0.085 & $\mathbf{0 . 0 0 2 8}$ \\
GOMVAC & 0.0362 & $\mathbf{0 . 0 3 7 6}$ & $\mathbf{0 . 0 3 9}$ & $\mathbf{0 . 0 1 0 6}$ & $\mathbf{0 . 0 0 1 7}$ & $\mathbf{0 . 0 2 1}$ & 0.219 & 0.3458 & $\mathbf{0 . 0 0 0 4}$ \\
$\approx$ & & $\mathbf{0 . 0 0 0 3}$ & 0.1365 & $\mathbf{0 . 0 2 9 3}$ & 0.1222 & $\mathbf{0 . 0 2 6 5}$ \\
HOSTOR & $\mathbf{0 . 0 4 3 3}$ & $\mathbf{0 . 0 5 0 1}$ & $\mathbf{0 . 0 4 6 8}$ & $\mathbf{0 . 0 5 7}$ & & 0.459 & 0.549 & 0.5931 & $\mathbf{0 . 0 0 0 1}$ \\
HOSKAM & $\mathbf{0 . 0 5 2 3}$ & 0.051 & $\mathbf{0 . 0 5 7 4}$ & 0.0512 & 0.0369 & & 0.4479 & 0.3201 & $\mathbf{0 . 0 2 3 7}$ \\
HOSKEL & 0.0378 & $\mathbf{0 . 0 4 4 3}$ & 0.0264 & $\mathbf{0 . 0 4 1 7}$ & 0.0242 & 0.0359 & & 0.8486 & $\mathbf{0 . 0 0 0 3}$ \\
HOSTOR2 & 0.0347 & 0.0462 & 0.0342 & 0.0505 & 0.0338 & 0.0524 & 0.0271 & & $\mathbf{0 . 0 0 6 8}$ \\
MORVER & $\mathbf{0 . 0 6 8}$ & $\mathbf{0 . 0 6 9}$ & $\mathbf{0 . 0 7 9}$ & $\mathbf{0 . 0 6 1 7}$ & $\mathbf{0 . 0 8 8 2}$ & $\mathbf{0 . 0 9 1 7}$ & $\mathbf{0 . 0 8 3 5}$ & $\mathbf{0 . 0 9 1 4}$ &
\end{tabular}

2 Significant differences are in bold. 


\section{Table 8 (on next page)}

Procrustes-distances $(P d)$ and $p$-values of Canonical Variates Analysis on gibel carp (Carassius gibelio) body shape.

Significant differences are in bold. 
1 Table 8. Procrustes-distances $(P d)$ and p-values of Canonical Variates Analysis on gibel

2 carp (Carassius gibelio) body shape.

\begin{tabular}{|c|c|c|c|c|}
\hline & \multicolumn{4}{|c|}{$p$-values } \\
\hline & GERCEG & GERTOR & HOSKEL & SZEBIC \\
\hline GERCEG & & $<.0001$ & 0.0047 & $<.0001$ \\
\hline GERTOR & 0.036 & & $<.0001$ & $<.0001$ \\
\hline HOSKEL & 0.0261 & 0.0438 & & $<.0001$ \\
\hline SZEBIC & 0.0247 & 0.0475 & 0.0441 & \\
\hline
\end{tabular}

3 Significant differences are in bold.

4 
Table 9 (on next page)

Procrustes-distances $(P d)$ and p-values of Canonical Variates Analysis on gibel carp (Carassius gibelio) scale shape.

Significant differences are in bold. 
1 Table 9. Procrustes-distances $(P d)$ and p-values of Canonical Variates Analysis on gibel

2 carp (Carassius gibelio) scale shape.

\begin{tabular}{lllllll} 
& \multicolumn{5}{c}{-values } \\
& & BENBIA & GERTOR & HOSKEL & HOSTOR & SZEBIC \\
BENBIA & & $\mathbf{0 . 0 0 0 2}$ & $\mathbf{0 . 0 1 7 5}$ & $\mathbf{0 . 0 1 3 7}$ & $\mathbf{0 . 0 0 3 8}$ \\
GERTOR & $\mathbf{0 . 0 6 7 6}$ & & 0.111 & $\mathbf{0 . 0 2 2 9}$ & 0.3999 \\
$\approx$ & HOSKEL & $\mathbf{0 . 0 6 0 1}$ & 0.0428 & & 0.5836 & 0.2426 \\
HOSTOR & $\mathbf{0 . 0 5 3 4}$ & $\mathbf{0 . 0 4 7 5}$ & 0.0346 & & 0.0854 \\
SZEBIC & $\mathbf{0 . 0 5 0 4}$ & 0.0246 & 0.037 & 0.038 &
\end{tabular}

3 Significant differences are in bold.

4 


\section{Table $\mathbf{1 0}$ (on next page)}

Proportion of significant background variables on fish body shape and scale shape.

Variable types: C - water chemistry data, PhAC - pharmaceutical active compound, LE - local environmental variables, LSE - landscape scale environmental variables. 
1 Table 10. Proportion of significant background variables on fish body shape and scale

2 shape.

\begin{tabular}{|c|c|c|c|c|c|}
\hline Species & $\begin{array}{l}\text { Analyzed } \\
\text { shape }\end{array}$ & $\begin{array}{l}\text { Variable } \\
\text { category }\end{array}$ & Significant variable & $\begin{array}{l}\text { Proportion } \\
\text { of effect }\end{array}$ & $\begin{array}{l}\text { Joint } \\
\text { effect }\end{array}$ \\
\hline \multirow{4}{*}{$\begin{array}{l}\frac{1}{0} \\
\text { : } \\
0\end{array}$} & scale & $\mathrm{C}$ & As & $9 \%$ & \\
\hline & & $\mathrm{C}$ & $\mathrm{SO}_{4}^{2-}$ & $3 \%$ & \\
\hline & body & $\mathrm{PhAC}$ & TRIM & $6 \%$ & \multirow{2}{*}{$1 \%$} \\
\hline & & $\mathrm{PhAC}$ & CITA & $4 \%$ & \\
\hline \multirow{8}{*}{$\frac{0}{\overrightarrow{0}}$} & scale & $\mathrm{C}$ & $\mathrm{Mg}$ & \multirow{3}{*}{$5 \%$} & \multirow{6}{*}{$1 \%$} \\
\hline & & $\mathrm{C}$ & As & & \\
\hline & & $\mathrm{C}$ & $\mathrm{Ca}$ & & \\
\hline & & LE & macrophyte coverage & \multirow{2}{*}{$2 \%$} & \\
\hline & & LE & water depth & & \\
\hline & & $\mathrm{PhAC}$ & CODE & $1 \%$ & \\
\hline & body & $\mathrm{LE}$ & detritus & $3 \%$ & \multirow{2}{*}{$8 \%$} \\
\hline & & $\mathrm{C}$ & $\mathrm{Cd}$ & $4 \%$ & \\
\hline \multirow{5}{*}{$\begin{array}{l}\text { 를 } \\
\frac{0}{0} \\
\frac{0}{00}\end{array}$} & scale & LSE & wetland & $6 \%$ & \multirow{2}{*}{$1 \%$} \\
\hline & & $\mathrm{C}$ & $\mathrm{Pb}$ & $2 \%$ & \\
\hline & body & $\mathrm{C}$ & $\mathrm{Zn}$ & $11 \%$ & \multirow{3}{*}{$4 \%$} \\
\hline & & LSE & catchment size & $2 \%$ & \\
\hline & & $\mathrm{PhAC}$ & PROP & $6 \%$ & \\
\hline
\end{tabular}

3 Variable types: $\mathrm{C}$ - water chemistry data, $\mathrm{PhAC}$ - pharmaceutical active compound, LE - local

4 environmental variables, LSE - landscape scale environmental variables. 